\title{
The post-Covid-19 era requires maximum urban resilience
}

\author{
Author: Abdol Aziz Shahraki \\ Senir Researcher at Kungliga Tekniska Högskolan, KTH. Skolan för Arkitektur och \\ samhällsbyggnad (ABE). Institutionen för stadsstudier och miljö. Email: sharaki@kth.se
}

\begin{abstract}
This paper reviews the low-resilience problem in many cities, poor designs of cities to cope with disasters, and the need for tolerance of urban constructions. It explores answers concerning the question of how shall we build cities resiliently? The method of this applied research is a multiphase process that considers all physical and socioeconomic elements of a city. It introduces six indicator groups of urban management (M), economy (E), built environments (U), Infrastructures (I), natural environments $(\mathrm{N})$, and health protection $(\mathrm{H})$. The groups include 55 indicators as variables in the mathematical calculations in this paper. This paper builds a mathematical model to maximize the profitability of resilient buildings by optimizing investments in the required projects. The projects will upgrade the firmness and tolerance of cities against nature-based and human-made dangers and risks.

There is linear programming in 55 variables to select optimal solutions from fifty-five factorial alternatives. Then, the programming will develop into non-linear programming. The unique innovation of this paper is its linear programming interpretation by non-linear to give optimal solutions for the problem. Applying the Lagrange function in the Kuhn-Tucker conditions proves the accuracy of the hypothesis that post-COVID urbanization requires maximum resilience. Only in this way, the urban economies will be free of risks.
\end{abstract} Outcomes in this paper will assist in the pre-planning, design, and building of built environments everywhere resilient and sustainable.

\section{Keywords}

Urban resilience; Physical elements of a city; Indicator groups; Linear programming; Maximum resilience profit; Optimal investment; Opportunity costs 


\section{Introduction}

The economic, social, technological, and political systems of cities are intertwined with radical changes (Ye et al., 2017). The history of human life reveals cities, which have been destroyed completely or partially by natural disasters, epidemics, and wars. In contrast, many cities demonstrated an astounding resilience by preparation for response to and recovering from natural and conflict disasters. For some time now, modern urbanization has realized that we must make cities resilient to threats and risks (Vale \& Campanella, 2005, Timmerman, 1981, Bostrom, 2002, and Ultramari \& Rezende, 2007).

Fastiggi et al. conducted semi-structured interviews with officials leading resilience efforts in 20 North American cities. Their interview questions focused on definitions of resilience, organizational structure, actor identification and involvement, internal coordination and communication, and external partnerships and engagement. They included cities facing various challenges and of different sizes to learn about coordination efforts in diverse contexts. The sample of 20 North American cities represented early adopters and leaders in resilience thinking, enabling the urban managers to learn about emerging resilience coordination strategies at a timely stage of institutionalization (Fastiggi et al., 2021). Resilience in cities is a broad and multifaceted concept, including urban management, the economy, and the relationship between social groups. It also encompasses regulations concerning the productive forces and the ecosystem of the city. Many urban managers look at urban resilience as a positive and flexible approach to succeed complex, interconnected, and unpredictable threats such as extreme weather, shifting climate, old infrastructure, and economic instability (Woodruff et al., 2018).

The urban resilience studies shall include a broad range of topics in planning history, modernization, cross-cultural exchange, colonization, urban morphology, comprehensive planning, and adaptive physical design, urban renovation and rehabilitation, the modern requirements of urban health protection, regional and environmental planning, wastewater collection and treatment, urban demographic development, urban economics, policymaking as related to danger; and the challenges facing cities around the world, and new emerging pandemic diseases. If you refer to the published work of Grant, you will see there that he is in common with our ideas to include the mentioned subjects in building cities' resilient process (Grant, 2006). 
One major topic in urban resilience studies is the contradictory urban processes of growth and shrinkage that constitute the overall pattern of growing urbanization worldwide. Multiple functions of urban vacant land have been rudimentary and subjective (Song et al., 2020). The necessity of strengthening cities exists when the COVID-19 global disaster devastates all communities economically and biotic. The need to redesign cities exists when the Coronavirus attack all communities economically and biotic. The pandemic revealed the need for urban spaces with different sizes and fewer crowds. The COVID-19 required new architectural and building standards and regulations.

We are aware of the danger is not only the killer viruses but also climate change. Floods, flu, animal diseases, locust infestations on farms and groves, sheltering farmers and ranchers in dilapidated cities, and those displaced by the urban economic network are natural or social crises. When faced with these threats, we need a new model for future planning and the physical planning of cities. We shall find new ways to protect urbanization against all possible present and coming threats.

Therefore, we ought to find answers to the following question: Who shall we plan and design cities better to help people cope with disasters, shocks, and risks? In other words, what projects shall we plan and implement to construct a resilient city?

This research increases the measurable ability of the urban system and its inhabitants to maintain a continuous life and safe, comfortable, and fair activities against all-natural or human-made shocks and pressures. Therefore, a city will be resilient when urban management has conducted the necessary assessment, planning, and measures to prevent, prepare and respond to natural, human-made, sudden, gradual, and unexpected hazards. Every city must be strong enough and flexible to protect and strengthen inhabitants' lives. Engineers shall use structural systems and building materials to meet the maximum stress tolerance.

Our research methods to achieve the goal are both theoretical and workshops. We review the ideas of scholars and the experiences of pragmatic engineers on building cities resilient and sustainable. Simultaneously, this research is an experimental study, and we benefit from our tests in urban planning and development workshops. From a practical perspective, we introduce indicators to assess the degree of resilience of cities. The indicator groups lead the city and setting its strategic goals concerning urban society and economy, urban built 
environment and infrastructure, the natural environment and hygiene, and citizens' health protection.

Outcomes of this research in the shape of a feasible model assist relevant actors in building cities resiliently.

\section{Methods and materials}

We rebuild a city resiliently in the process. The first step in the process is to clarify the current situation in rigidity and decision making. At this stage, we introduce some indicators to identify the risks, shocks, and disasters that threaten the city. The second step is to determine an optimal resilience situation that the city wants to achieve. The third step is to explain how it achieves that vision of resistance. This step requires definition, planning, and implementation of projects, which we shall perform. The scope of our field study is global, as the epidemic of Covis-19 disease swept across the globe, and all cities more or less acknowledged the need for sustainability. Scientists have developed indicators to measure the resilience of cities to disasters. But as many experts declared, and in our opinion, those indicators did not cover all aspects of a city (Tan et al., 2017, Gutter, 2016 and Copeland, 2020). Using the opinions of scholars and scientists by structural interviews and our field and workshop experiences, we extract indicators to guide our measurement and practice in the three steps of this process. Table 1 introduces indicators that assist us in measuring the rate of the resilience of a given city. 
Table 1 Indicators for measuring the resilience of cities

\begin{tabular}{|c|c|c|c|}
\hline 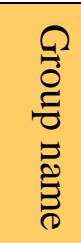 & $\frac{3}{\sum_{\pi}^{2}}$ & The purpose of the index & Indicators \\
\hline 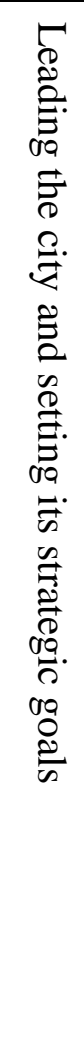 & $M$ & 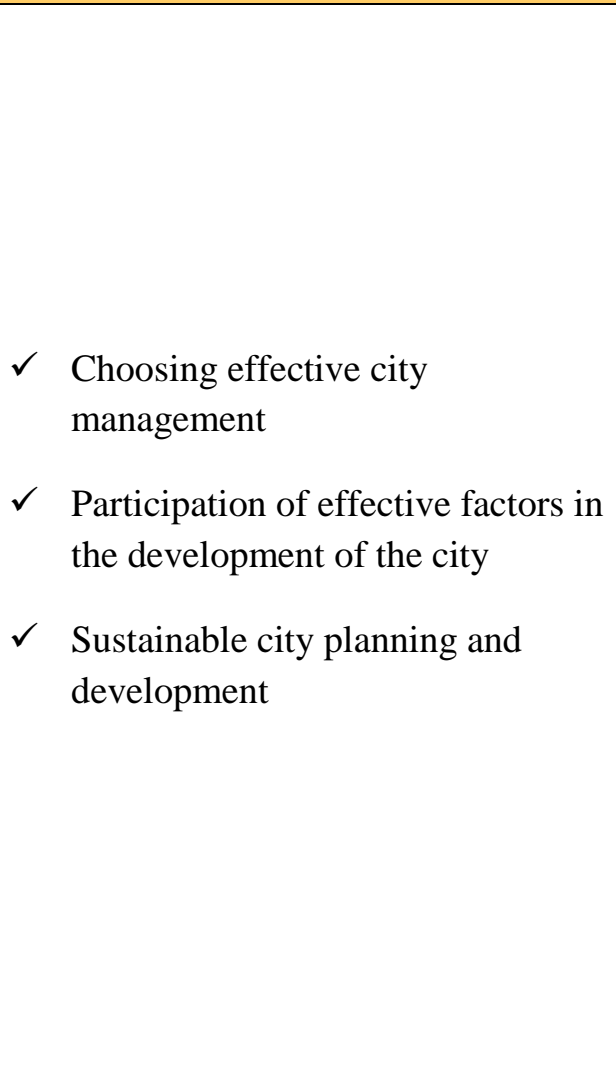 & $\begin{array}{l}\text { 1. Training competent, qualified, and } \\
\text { specialized managers to lead the city } \\
\text { 2. Appropriate decision making in the public } \\
\text { interest of citizens } \\
\text { 3. Efficient coordination of urban management } \\
\text { and all administrative components } \\
\text { 4. Encourage active cooperation between } \\
\text { various groups in society } \\
\text { 5. Prepare a comprehensive plan to protect the } \\
\text { city from possible damage } \\
\text { 6. Preparation of projects with details of control } \\
\text { and elimination of urban damages } \\
\text { 7. Set up a city emergency management plan } \\
\text { 8. Education, publicity, and widespread } \\
\text { awakening of urban society from potential } \\
\text { risks } \\
\text { 9. Defining an efficient mechanism of } \\
\text { community interaction with urban } \\
\text { management during disasters } \\
\text { 10. Establish fair and efficient urban land-use } \\
\text { policies } \\
\text { 11. Transparent and comprehensive processes for } \\
\text { approving urban programs }\end{array}$ \\
\hline 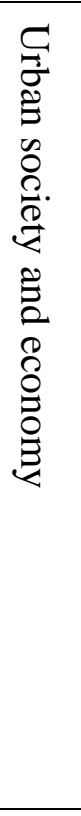 & $E$ & $\begin{array}{ll}\checkmark & \text { Sustainable development of the } \\
& \text { urban economy } \\
\checkmark & \text { Ensuring security and fair rule of } \\
& \text { law } \\
\checkmark & \text { Socio-economic support for all } \\
\text { people }\end{array}$ & $\begin{array}{l}\text { 1. Strong integration with peripheral, regional, } \\
\text { and global economies } \\
\text { 2. Measuring the attractiveness of city business } \\
\text { environments } \\
\text { 3. Number of comprehensive business plans in } \\
\text { the city } \\
\text { 4. People's access to civil and criminal justice } \\
\text { 5. People's opinion on police competence } \\
\text { 6. Existence of active mechanisms to prevent } \\
\text { corruption } \\
\text { 7. Existence of effective crime prevention } \\
\text { systems } \\
\text { 8. Citizen participation rates in urban events } \\
\text { 9. The degree of consideration of the identity } \\
\text { and culture of the city } \\
\text { 10. Guaranteeing organizations and civil society } \\
\text { 11. Mechanism of citizens' access to an } \\
\text { appropriate work } \\
\text { 12. Mechanisms for supporting the unemployed } \\
\text { and the needy }\end{array}$ \\
\hline
\end{tabular}




\begin{tabular}{|c|c|c|c|}
\hline 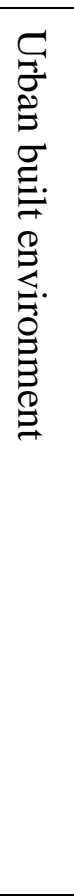 & $U$ & $\begin{array}{ll}\checkmark & \text { Physical design of the city } \\
\text { according to the urban land use } \\
\text { plan } \\
\checkmark & \text { Effective provision of housing } \\
& \text { services } \\
\checkmark & \text { Construction of essential urban } \\
\checkmark & \text { spaces of the city } \\
\checkmark & \text { Respecting building standards and } \\
\text { codes in constructions }\end{array}$ & \begin{tabular}{|l} 
1. Allocate sufficient land to streets and \\
passages \\
2. Existence of mechanisms for people to access \\
housing with the necessary standards \\
3. Existence of protocols for providing housing \\
for low-income citizens \\
4. There are adequate urban spaces such as \\
schools, workshops, businesses, stadiums, \\
etc. \\
5. Active mechanisms for maintenance of urban \\
spaces \\
6. Ensure the maintenance of spare parts to \\
provide effective urban services \\
7. Provide flexible urban services to the people \\
8. Introducing guidelines, codes, and \\
appropriate city standards for construction \\
9. Ensure effective implementation of \\
construction laws and prevention of \\
violations \\
10. Prepare a comprehensive construction plan of \\
the city with details of areas at risk and \\
damage
\end{tabular} \\
\hline 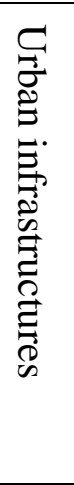 & - & $\begin{array}{ll}\checkmark & \text { Provision of all required urban } \\
\text { infrastructures } \\
\checkmark & \text { Build a reliable transportation } \\
\text { network } \\
\checkmark & \text { Build a reliable } \\
\text { telecommunications and digital } \\
\text { communication network }\end{array}$ & \begin{tabular}{|l} 
1. \\
Effective monitoring of robust protective \\
infrastructure \\
2. Existence of safe and reliable transportation \\
networks in the city \\
3. Existence of digital networks and reliable \\
communication technology \\
4. Maximum water supply and minimum water \\
consumption \\
5. Power and gas supply and distribution \\
networks \\
6. Fair access to electricity, gas, gasoline, etc. \\
7. Collecting and treating wastewaters
\end{tabular} \\
\hline 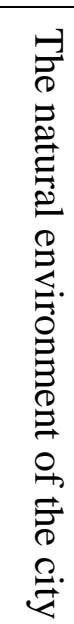 & $N$ & $\begin{array}{ll}\checkmark & \text { Preservation of natural resources of } \\
\text { the city } \\
\checkmark & \text { Preservation of natural } \\
\text { environmental components } \\
\checkmark & \text { Cleanliness of citizens' } \\
\text { environment }\end{array}$ & $\begin{array}{l}\text { 1. Existence of soil protection mechanisms } \\
\text { 2. Existence of water resources } \\
\text { conservation mechanisms } \\
\text { 3. Existence of mechanisms for keeping } \\
\text { plants and birds } \\
\text { 4. How to collect urban wastewater } \\
\text { 5. The purity of the city's water } \\
\text { 6. The amount of clean air in the city } \\
\text { 7. Noise pollution in the city } \\
\text { 8. Mechanisms for keeping the } \\
\text { environment clean from pollution }\end{array}$ \\
\hline
\end{tabular}




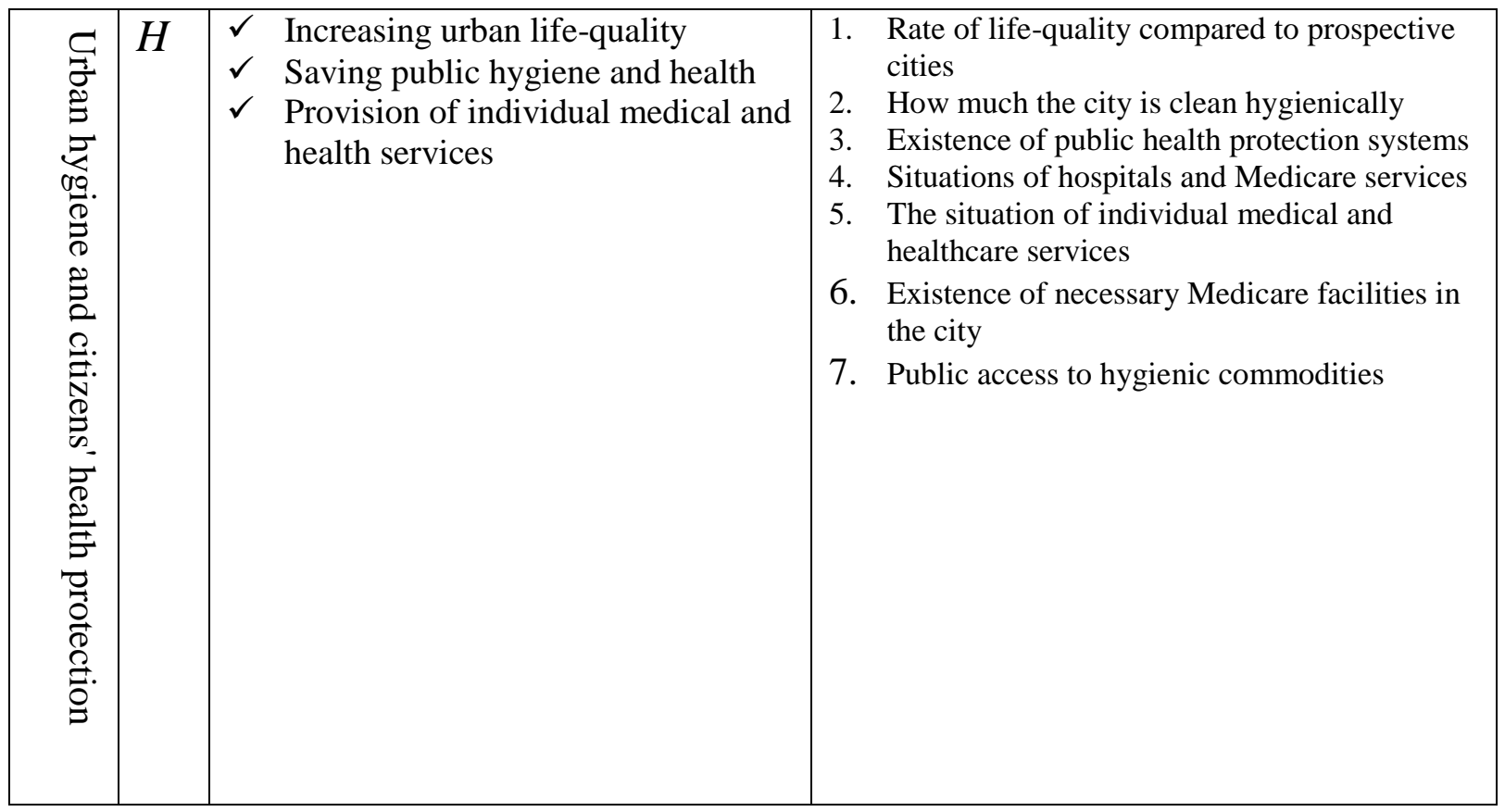

Table 1 has four columns. The left column names the indicator groups. The second column marks indicator groups. The next column expresses the purposes of the indicator groups. The far-right column lists the indicators in every group. With the help of this table, we program a linear plan and determine the amount of investment in each indicator group to achieve the best economic profit by the maximum resilience of the city. By setting strategic policies for the socio-economic and physical development of the city, we will illustrate a model that makes the city resilient. The work is possible with classic methods, experiments, and forecasting techniques to picture the future.

We build a general mathematical program to show the resilient model every city will apply to respect its particular characteristics.

Our mathematical model begins with an allocation method that is a linear programming technique for determining an optimal allocation of funds. This technique is an optimal allocation schedule. With this simple linear programming technique, we improve $\mathrm{n}$ indicators by one of the $\mathrm{n}$ projects. Each project is for only one indicator. We exhibit the condition results in a square matrix, where the number of projects and indicators is equal. 
Table 2 Matrix of Leading the city and setting its strategic goals group of indicators with alternative investment amounts in projects

\begin{tabular}{|l|l|l|l|l|l|l|l|l|l|l|l|l|}
\hline \multicolumn{7}{|c|}{ Optimal investment on projects/\$ } \\
\cline { 2 - 11 } \\
\hline Indicator Mlt
\end{tabular}

The above square matrix has eleven columns and rows. The first left side column shows the $M_{i}$ group of indicators. Other columns exhibit alternative investment amounts in projects to upgrade the resiliently of the city. For example cell of $F_{11} \$$ shows the amount of investment in the project related to the indicator of 'Selecting competent, qualified, and specialized managers to lead the city', $M_{l}$. Similarly, the cell of $F_{1111} \$$ is the investment in projects on the 'Transparent and comprehensive processes for approving urban programs', $M_{11}$. This matrix with 11 indicators and 11 alternatives of project investment has 11 !equal to 39916800 solutions. For determining optimal investment in projects of $M_{i}$ group indicators, we try all 39916800 possibilities and select the best for every project to meet maximal urban resilience. Here, we are writing our simplex method for the solution of the matrix.

Optimize $\sum_{i=1}^{11} \sum_{j=1}^{11} F_{i j} M_{i j}$

$$
\text { For } i=1,2, \ldots, n \text {, and } j=1,2, \ldots, n \text {, }
$$

Similarly, we write a $12 \times 12$ square matrix for the index group of $E_{i}$, and as a result we have
Optimize $\sum_{i=1}^{12} \sum_{j=1}^{12} F_{i j} E_{i j}$
For $i=1,2, \ldots, n$, and $j=1,2, \ldots, n$, 
We write optimization functions for indicators of the urban built environment, $U_{i}$, urban infrastructures, $I_{i}$, and the natural environment of the city $N_{i}$ as well.
Optimize $\sum_{i=1}^{10} \sum_{j=1}^{10} F_{i j} U_{i j}$
(3) For $i=1,2, \ldots, n$, and $j=1,2, \ldots, n$,
Optimize $\sum_{i=1}^{7} \sum_{j=1}^{7} F_{i j} I_{i j}$
(4) For $i=1,2, \ldots, n$, and $j=1,2, \ldots, n$,
Optimize $\sum_{i=1}^{8} \sum_{j=1}^{8} F_{i j} N_{i j}$
(5) For $i=1,2, \ldots, n$, and $j=1,2, \ldots, n$,

The COVID-19 epidemic took the world by surprise and caused many catastrophes. For this reason, we highlight the urban hygiene and health protection group of indicators. We cannot build cities resiliently without quantitative and qualitative improvements of the Hi. Here, we complete the matrix table group $\mathrm{Hi}$, as before, and write its optimization function.

Table 3 Matrix of urban hygiene and citizens' health protection groups of indicators with alternative investment amounts in projects

\begin{tabular}{|c|c|c|c|c|c|c|c|}
\hline \multirow[b]{2}{*}{ Indicator $\mathrm{H}$} & \multicolumn{7}{|c|}{ Optimal investment on projects/\$ } \\
\hline & Alt $_{1}$ & Alt $_{2}$ & Alt $_{3}$ & Alt $_{4}$ & Alt $_{5}$ & Alt 6 & Alt $_{7}$ \\
\hline$H_{1}$ & $\overline{\mathrm{F}_{11} \$}$ & $\overline{\mathrm{F}_{12} \$}$ & $\overline{\mathrm{F}_{13} \$}$ & $\mathrm{~F}_{14} \$$ & $\mathrm{~F}_{15} \$$ & $\mathrm{~F}_{16} \$$ & $\overline{\mathrm{F}_{17} \$}$ \\
\hline $\mathrm{H}_{2}$ & $\mathrm{~F}_{21} \$$ & $\mathrm{~F}_{22} \$$ & $\mathrm{~F}_{23} \$$ & $\mathrm{~F}_{24} \$$ & $\mathrm{~F}_{25} \$$ & $\mathrm{~F}_{26} \$$ & $\mathrm{~F}_{27} \$$ \\
\hline $\mathrm{H}_{3}$ & $\mathrm{~F}_{31} \$$ & $\mathrm{~F}_{32} \$$ & $\mathrm{~F}_{33} \$$ & $\mathrm{~F}_{34} \$$ & $\mathrm{~F}_{35} \$$ & $\mathrm{~F}_{36} \$$ & $\mathrm{~F}_{37} \$$ \\
\hline $\mathrm{H}_{4}$ & $\mathrm{~F}_{41} \$$ & $\mathrm{~F}_{42} \$$ & $\mathrm{~F}_{43} \$$ & $\mathrm{~F}_{44} \$$ & $\mathrm{~F}_{45} \$$ & $\mathrm{~F}_{46} \$$ & $\mathrm{~F}_{47} \$$ \\
\hline$H_{5}$ & $\mathrm{~F}_{51} \$$ & $\mathrm{~F}_{52} \$$ & $\mathrm{~F}_{53} \$$ & $\mathrm{~F}_{54} \$$ & $\mathrm{~F}_{55} \$$ & $\mathrm{~F}_{56} \$$ & $\mathrm{~F}_{57} \$$ \\
\hline$H_{6}$ & $\mathrm{~F}_{61} \$$ & $\mathrm{~F}_{62} \$$ & $\mathrm{~F}_{63} \$$ & $\mathrm{~F}_{64} \$$ & $\mathrm{~F}_{65} \$$ & $\mathrm{~F}_{66} \$$ & $\mathrm{~F}_{67} \$$ \\
\hline $\mathrm{H}_{7}$ & $\mathrm{~F}_{71} \$$ & $\mathrm{~F}_{72} \$$ & $\mathrm{~F}_{73} \$$ & $\mathrm{~F}_{74} \$$ & $\mathrm{~F}_{75} \$$ & $\mathrm{~F}_{76} \$$ & $\mathrm{~F}_{77} \$$ \\
\hline
\end{tabular}

Optimize $\sum_{i=1}^{7} \sum_{j=1}^{7} F_{i j} H_{i j}$ (6) For $i=1,2, \ldots, n$, and $j=1,2, \ldots, n$,

Finally, we can complete the model of urban resilience and write the equation of maximizing profit from urban resilience. Using the sum of optimal investment functions in quantitative and qualitative improvement projects, we have 55 indicators in 6 main groups:

$$
R_{\text {Profit }}=\left(\sum_{i=1}^{11} \sum_{j=1}^{11} F_{i j} M_{i j}+\sum_{i=1}^{12} \sum_{j=1}^{12} F_{i j} E_{i j}+\sum_{i=1}^{10} \sum_{j=1}^{10} F_{i j} U_{i j}+\sum_{i=1}^{7} \sum_{j=1}^{7} F_{i j} I_{i j}+\sum_{i=1}^{8} \sum_{j=1}^{8} F_{i j} N_{i j} \sum_{i=1}^{7} \sum_{j=1}^{7} F_{i j} H_{i j}\right) \text { (7) }
$$


Therefore, we set up a matrix for all indicators in (7) to be upgraded and suitable for a resilient city. In equation (7), our variables are unstable, which varies in different situations. We have 55 indicators in Table 4.

Table 4 Matrix of all groups of indicators with alternative investment amounts in projects

\begin{tabular}{|c|c|c|c|c|c|c|c|c|c|}
\hline \multirow{2}{*}{$\begin{array}{l}\text { Indicators of } \\
\text { OPI }\end{array}$} & \multicolumn{9}{|c|}{ Optimal investment on projects/\$ } \\
\hline & Alt $_{1}$ & Alt $_{2}$ & Alt $_{3}$ & Alt $_{4}$ & & $\cdot$ & . & Alt 54 & Alt 55 \\
\hline$O P I_{1}$ & $\mathrm{~F}_{11} \$$ & $\mathrm{~F}_{12} \$$ & $\mathrm{~F}_{13} \$$ & $\mathrm{~F}_{14} \$$ & 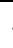 & $\cdot$ & . & $\mathrm{F}_{154} \$$ & $\mathrm{~F}_{155} \$$ \\
\hline $\mathrm{OPI}_{2}$ & $\mathrm{~F}_{21} \$$ & $\mathrm{~F}_{22} \$$ & $\mathrm{~F}_{23} \$$ & $\mathrm{~F}_{24} \$$ & . & . & . & $\mathrm{F}_{254} \$$ & $\mathrm{~F}_{255} \$$ \\
\hline $\mathrm{OPI}_{3}$ & $\mathrm{~F}_{31} \$$ & $\mathrm{~F}_{32} \$$ & $\mathrm{~F}_{33} \$$ & $\mathrm{~F}_{34} \$$ & 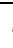 & $\cdot$ & . & $\mathrm{F}_{354} \$$ & $\mathrm{~F}_{355} \$$ \\
\hline $\mathrm{OPI}_{4}$ & $\mathrm{~F}_{41} \$$ & $\mathrm{~F}_{42} \$$ & $\mathrm{~F}_{43} \$$ & $\mathrm{~F}_{44} \$$ & 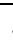 & $\cdot$ & . & $\mathrm{F}_{454} \$$ & $\mathrm{~F}_{455} \$$ \\
\hline . & . & . & & . & & $\cdot$ & · & . & $\cdot$ \\
\hline . & . & . & . & . & & · & . & . & e \\
\hline . & . & . & & . & & . & · & . & - \\
\hline$O P I_{54}$ & $\mathrm{~F}_{541} \$$ & $\mathrm{~F}_{542} \$$ & $\mathrm{~F}_{543} \$$ & $\mathrm{~F}_{544} \$$ & . & $\cdot$ & . & $\mathrm{F}_{5454} \$$ & $\mathrm{~F}_{5455} \$$ \\
\hline$O P I_{55}$ & $\mathrm{~F}_{551} \$$ & $\mathrm{~F}_{552} \$$ & $\mathrm{~F}_{553} \$$ & $\mathrm{~F}_{554} \$$ & & & - & $\mathrm{F}_{5554} \$$ & $\mathrm{~F}_{5555} \$$ \\
\hline
\end{tabular}

In the above matrix, 55! solutions exist, but we find only 55 optimal investments in the projects related to the improvement of 55 indicators.

From Table $4 \Rightarrow$ Maximize $R_{\text {Profit }}=\sum_{i=1}^{55} \sum_{j=1}^{55} F_{i j} O \mathrm{P} I_{i j}$

We have quantified our parameters in terms of monetary gain for the city through its resilience. In objective equation of (8) $R_{\text {Profit }}$ is the profit caused by resilient building of a given city per $\$$ and $O P I$ is the optimal projects' investment to improve the indicators. In maximization equation (8): $1 \leq i$ and $j \leq 55$.

In the third step, to achieve the maximum profit produced by making the city resilient, it is necessary to prepare a comprehensive program that includes projects to improve the indicators. The program with underlying projects brings the city to its goal of maximum resilience and economic benefits. 


\section{Experiences and results}

We experienced many cities in the world are unable to protect their residents from potential risks such as flood, earthquake, tsunami, sandstorm, drought, famine, etc. (Shahraki, 2020, World Health Organization, 2017, and Siegel, 2018). Most of the world's inhabitants are now defenceless even against predictable events such as rain, sandstorms, cold and extreme heat. The goal of resilience in the city is to protect it against such threats.

In the first step, we shall clarify the current situation and recognize the shocks and disasters that threaten it. For this reason, we analyze the components of each city. The following are generic elements of a city:

- Built environments, including the skeleton and physics of the city, in terms of quantitative and qualitative standards applied in homes and urban spaces.

- Land-use policies in terms of land allocation for housing, streets, hospitals, workplaces, schools, sports, recreation, etc. Public access to urban spaces and infrastructures is a standard.

- Basic urban infrastructures, including the supply and distribution of energy and water, waste and sewage collection, telecommunications, and urban and suburban transportation networks.

- Hardware and software infrastructure of health and medical care in terms of adequacy per capita and expertise and equipment needed to deal with epidemic disease crises.

- Municipal public services, including cemeteries, parks, and administrative services related to construction.

- Rule of law from the perspectives of social justice, development of civil society organizations, and respect for human rights, women, children, animals, environment, and peace.

- Preservation and development of the cultural, natural, and historical heritage of the city.

- An economy includes the diversity of economic sectors and stability and efficient marketing. Additionally, the development of unique capacities of the city and emphasis on strengthening its economic potentials is a way to sustainable development.

Knowing the physical and characteristics of every city is possible with field research tools. Case studies and experiences assist us in risks, shocks, and disasters that threaten the city. Table 5 shows some dangers that threaten cities. 
Table 5 risks threaten unstable and unsustainable cities.

\begin{tabular}{|c|c|}
\hline Line & Name of risks \\
\hline 1 & Failure consequences of macro-socio-economic programs. \\
\hline 2 & Consequences of non-realized urban development prediction and national plans of previous decades. \\
\hline 3 & $\begin{array}{l}\text { The migration of unemployed farmer migration. Similarly, the fisher moved to the city that increases } \\
\text { the residential density. }\end{array}$ \\
\hline 4 & $\begin{array}{l}\text { The collapse of the labor market, the increase in unemployment, and the homeless phenomenon resulted } \\
\text { in social unrest. }\end{array}$ \\
\hline 5 & The problem caused by an unlicensed population and children in war-torn cities. \\
\hline 6 & The growing crisis of the expansion of suburban areas in cities \\
\hline 7 & Crisis of expansion of worn-out areas of cities \\
\hline 8 & An increasing number of people are losing their homes in the current economic crisis. \\
\hline 9 & The crisis of poor, unemployed, and oppressed women \\
\hline 10 & The growing crisis of working and sexually abused children \\
\hline 11 & $\begin{array}{l}\text { The crisis caused by climate change and the expansion of unsuitable constructions with the climate of } \\
\text { the city }\end{array}$ \\
\hline 12 & Drought crisis \\
\hline 13 & Danger of sudden and devastating floods \\
\hline 14 & Tsunami risk \\
\hline 15 & Risk of volcanic activity overlooking the city \\
\hline 16 & Risk of collapse of unstable and nonresistant buildings \\
\hline 17 & Risk of landslides and landslides and slopes and landslides \\
\hline 18 & Earthquake risk \\
\hline 19 & Risk of sandstorm attacks \\
\hline 20 & The danger of disconnection of unstable water sources that comes from a distance \\
\hline 21 & $\begin{array}{l}\text { Industrial, hospitals, and household sewage flows and surface water in the city that help spread } \\
\text { infectious diseases. }\end{array}$ \\
\hline 22 & Risk of interruption of transport networks and suburban traffic \\
\hline 23 & $\begin{array}{l}\text { The problem of the narrowness of passages, stations, and offices of transportation and traffic and high } \\
\text { population density in these places }\end{array}$ \\
\hline 24 & $\begin{array}{l}\text { The problem of interruption in electronic communications and telecommunications due to their } \\
\text { inefficiency or the decisions of the rulers of the countries }\end{array}$ \\
\hline 25 & Risks of shortage and improper distribution of fossil fuels such as oil, gas, diesel, and gasoline \\
\hline 26 & Risks of power outages \\
\hline 27 & Risk of epidemic diseases in the city \\
\hline 28 & Lack of hospitals, clinics, laboratories, nurses and doctors \\
\hline 29 & Risk of epidemic diseases in livestock and poultry \\
\hline 30 & Lack of veterinarian and equipment and medicines for livestock \\
\hline 31 & Risk of epidemic diseases in plants and trees and lack of pesticides \\
\hline 32 & The danger of locust infestation, and pests. Lack of aircraft and spraying equipment. \\
\hline 33 & Risks of food shortages and famines and food insecurity \\
\hline 34 & Shocks by military action, war, and the lack of any shelter for civilians. \\
\hline 35 & Lack of adequate firefighting equipment and assistance to the injured \\
\hline 36 & Short knowledge, technologies, and machinery to fight natural disasters \\
\hline 37 & Poor regional and interregional collaboration networks with peripheral cities \\
\hline
\end{tabular}

Characteristics of cities based on our observation and experiences prove the existence of risks listed in Table 5. During recent decades, cities have experienced numerous economic, demographic, social, cultural, climate, physical, environmental, and exosystemic changes.

Table 5 shows the changes that risks make in cities. The increase in the population of cities 
has caused the need for more urban spaces and streets, and passages. In densely populated cities, people are now fleeing from each other and distance themselves physically from others to escape the coronavirus, but to no avail. All bus stops, trains, and vehicles are crowded. In parallel, the physical expansion of cities destroyed their natural and organic systems. Research shows that the Coronavirus has lived in the glaciers located in the poles for billions of years (Taillant, 2021). But by destroying the environment and melting glaciers, humans destroyed the invasive viruses and brought it into his life (Kumar et al., 2021 and Epstein \& Mills, 2005). Some scholars highlighted the risks associated with viruses hidden in permafrost, and the risks arising out of ecological destruction (Dash et al., 2021). The destruction of ecosystems by increasing urbanization is not the only current problem, but also the increasing populations in cities reduces vegetation and increases carbon, waste and sewage production, and soil erosion. Poor inhabitants spread infectious viruses through running sewers ( Shahraki, 2021). COVID-19's one-year experience revealed that cities were helpless against the coronavirus despite their arrogant medical and pharmaceutical advances over the centuries. Hospitals do not have enough space for patients and medical facilities. We agree with Narwhal \& Jain that recently said "Build resilient health systems" (Narwal \& Jain, 2021). We observed the relationship between individuals and general health indices with environmental and ecosystem factors. Other experiences show the same relationship as Mapar et al., who wrote "The results showed that safety theme and environmental themes are important in the municipal sustainability performance" (Mapar et al., 2020).

The second step determines what model of resilience is pertinent to the city.

We suggested the resilience model by setting strategic policies for economic, social, and physical development with classic and experienced models of forecasting and scenarios. We are aware that cities are complex and dynamic systems. They operate to link the natural and built environments with human processes. Therefore, the suggested mode to make cities resilient is complex.

By learning from the experiences and knowledge of a given city, we plan and design it resiliently. The World Health Organization has particular urban settings in health, social services, transport, housing and energy, education, water supply, and distribution, etc. The settings prepare cities against COVID-19 (World Health Organization, 2020). The United Nations Office for Disaster Risk Reduction, UNDRR, with lessons learned from the hurt cities, suggested ten essentials for making cities resilient (Schofield \& Twigg, 2019). They organize disaster resilience, identifying, understanding, and using current and future risk 
scenarios. They recommended financial capacity for resilience, pursue resilient urban development and design, and safeguard natural buffers to enhance ecosystems' protective functions. They recommend strengthening the institutional capacity for societal resilience, improvement of infrastructure, effective response to disaster, and expedite build back better. The actions should be part of the disaster resilience and urban development planning model. Other scientists also suggested resilient models for cities. "Scientists proposed rigorous models of urban resilience with multidisciplinary and integrated approaches based on humane perspectives" (OECD, 2020). Scientists proposed rigorous models of urban resilience by multidisciplinary and integrated approaches based on human perspectives (Bozza et al., 2015). Our workshops were on effective management and public participation. We worked to integrate the planning of the urban economy with the physical development of the city. Transparent management is necessary to know and cooperate with effective actors in the development of the city. Here, we supply a generic list of effective actors, but every city shall consider its own needs.

Table 6 a generic list of forces and actors influencing matters related to urban resilience

\begin{tabular}{|l|l|}
\hline Line & \multicolumn{1}{|c|}{ Name of force/ organization/ influential factor } \\
\hline 1 & Representatives of government departments, who are representatives of the executive branch in the city \\
\hline 2 & Representatives of the judiciary in the city in the form of the judiciary, courts, judges, and lawyers \\
\hline 3 & Representatives of the legislature in the form of representatives of the people of the city in parliament \\
\hline 4 & Representatives of the city council \\
\hline 5 & Representatives of the Guild Council \\
\hline 6 & Representatives of employers' organizations \\
\hline 7 & Representatives of existing banks in the city \\
\hline 8 & Indigenous investors of the city and province \\
\hline 9 & Representatives of investors from all over the country \\
\hline 10 & Representatives of International Investors \\
\hline 11 & Educated, specialists, and sympathizers of the city \\
\hline 12 & Representatives of trade unions in democracies \\
\hline 13 & Representatives of non-governmental organizations \\
\hline 14 & Representatives of radio and television, national government newspapers \\
\hline 15 & Representatives of local radio and television in democracies \\
\hline 16 & Representatives of local and indigenous newspapers of the city \\
\hline 17 & Representatives of international resilience organizations of world cities such as the World Bank Group \\
\hline
\end{tabular}

Urban resilience is feasible by secure livelihoods and employment. It requires the provision of municipal services such as transportation infrastructure and reliable communications. The urban development model should reduce risk and harm to minimize human vulnerability, the lives and health of citizens, and comprehensive security and the rule of law. 
Our model for urban resilience maximizes the benefits through optimal investment to upgrade 55 indicators. See Objective function (8). We think this generic model is feasible in every city after analyzing the risks and vulnerabilities of the city. The implementation of this model strengthens and sustains cities in six M, E, U, I, N, and $\mathrm{H}$ indicator groups. It also brings economic prosperity. We achieve this goal by implementing the projects that we define and implement in detail in the third step of the resilience process.

The third step explains how the city achieves the determined vision of resilience. This step reflects the present situation of the city and exhibits its future. In the third step, we introduce projects for every indicator, explain them in detail, and determine an optimal amount of investment in the projects. See equations (1)-(6). Table 7 suggests generic projects to upgrade the situation of the indicators briefly. Local planners and engineers shall explain every project in detail with an acting schedule and investment plan according to the characteristics of their cities.

Table 7 a list of required projects to build a city resilient

\begin{tabular}{|c|c|c|}
\hline Line & Indicator & Introducing projects to upgrade the city's resilient \\
\hline 1 & $\mathrm{M}_{1}$ & $\begin{array}{l}\text { Projects of the urban management training program at the university with a number of elite } \\
\text { volunteers. }\end{array}$ \\
\hline 2 & $\mathrm{M}_{2}$ & $\begin{array}{l}\text { Project to form decision-making groups by selecting people for urban areas and the whole } \\
\text { city. }\end{array}$ \\
\hline 3 & $\mathrm{M}_{3}$ & $\begin{array}{l}\text { A project on integrated and coordinated planning and management plan consisting of } \\
\text { representatives of all public and private sectors of the city. }\end{array}$ \\
\hline 4 & $\mathrm{M}_{4}$ & $\begin{array}{l}\text { Project of preparing propaganda programs for lectures, videos, and meetings for active } \\
\text { participation of people in the management and monitoring of the city }\end{array}$ \\
\hline 5 & $\mathrm{M}_{5}$ & $\begin{array}{l}\text { Project to prepare a comprehensive city planning program to deal with various potential } \\
\text { risks }\end{array}$ \\
\hline 6 & $\mathrm{M}_{6}$ & $\begin{array}{l}\text { Project for the preparation of a comprehensive program for the elimination of physical, } \\
\text { natural, and human risk factors and factors by urban management }\end{array}$ \\
\hline 7 & $\mathrm{M}_{7}$ & Project to prepare an emergency management plan for the city \\
\hline 8 & $\mathrm{M}_{8}$ & $\begin{array}{l}\text { A project for public education and awareness of the people of the city to deal with possible } \\
\text { dangers prepared by the city manager }\end{array}$ \\
\hline 9 & $\mathrm{M}_{9}$ & $\begin{array}{l}\text { Project to prepare and define the mechanism of people interaction and management in } \\
\text { times of crisis }\end{array}$ \\
\hline 10 & $\mathrm{M}_{10}$ & Project to set fair and efficient urban land policies \\
\hline 11 & $\mathrm{M}_{11}$ & $\begin{array}{l}\text { Project to set up a comprehensive and transparent mechanism for the approval of urban } \\
\text { development plans }\end{array}$ \\
\hline 12 & $\mathrm{E}_{1}$ & $\begin{array}{l}\text { Project for evaluating and feasibility of economic and commercial cooperation with cities } \\
\text { and surrounding areas. Also, if possible, conclude trade agreements and economic } \\
\text { partnerships. }\end{array}$ \\
\hline 13 & $\mathrm{E}_{2}$ & $\begin{array}{l}\text { Project to measure the unique economic capabilities of the city and plan to use these } \\
\text { facilities }\end{array}$ \\
\hline 14 & $\mathrm{E}_{3}$ & Project to prepare business plans in various economic sectors \\
\hline 15 & $\mathrm{E}_{4}$ & Project to provide a mechanism for public access to judicial justice \\
\hline 16 & $\mathrm{E}_{5}$ & $\begin{array}{l}\text { Project to provide a mechanism for influencing the opinion of inhabitants to determine the } \\
\text { duties and behavior of the police. }\end{array}$ \\
\hline
\end{tabular}




\begin{tabular}{|c|c|c|}
\hline 17 & $\mathrm{E}_{6}$ & Project to provide effective mechanisms for combating government corruption. \\
\hline 18 & $\mathrm{E}_{7}$ & Project for the preparation of social programs for crime prevention. \\
\hline 19 & $\mathrm{E}_{8}$ & $\begin{array}{l}\text { Project for preparing mechanisms to increase the rate of social participation in economic } \\
\text { and social activities of the city }\end{array}$ \\
\hline 20 & $\mathrm{E}_{9}$ & Project to integrate the identity and culture of the city in economic and social activities \\
\hline 21 & $\mathrm{E}_{10}$ & $\begin{array}{l}\text { Project to provide mechanisms to guarantee the legal activities of democratic groups of the } \\
\text { people. }\end{array}$ \\
\hline 22 & $\mathrm{E}_{11}$ & $\begin{array}{l}\text { Project to provide mechanisms for fair and meritorious access of people in the community } \\
\text { to job opportunities and banking facilities. }\end{array}$ \\
\hline 23 & $\mathrm{E}_{12}$ & $\begin{array}{l}\text { Project to provide efficient and guaranteed mechanisms on the unemployed and the needy. } \\
\text { The project also monitors that city administrations do not relinquish their duties under the } \\
\text { pretext of helping compassionate people. }\end{array}$ \\
\hline 24 & $\mathrm{U}_{1}$ & $\begin{array}{l}\text { Projects to review previous land-use policies and setting new policies to design streets, } \\
\text { sidewalks, stations and reduce population density in urban spaces. }\end{array}$ \\
\hline 25 & $\mathrm{U}_{2}$ & $\begin{array}{l}\text { Projects for standard housing to increase per capita housing in the city suitable for modern } \\
\text { human needs. }\end{array}$ \\
\hline 26 & $\mathrm{U}_{3}$ & Projects of standard housing for low-income groups to have access to housing. \\
\hline 27 & $\mathrm{U}_{4}$ & $\begin{array}{l}\text { Projects to allocate sufficient land for constructing schools, stadiums, workshops, and } \\
\text { commercial centers and reduce the population density. }\end{array}$ \\
\hline 28 & $\mathrm{U}_{5}$ & Project for maintenance of urban spaces \\
\hline 29 & $\mathrm{U}_{6}$ & Project for the maintenance of the components of the city to provide services to the citizens \\
\hline 30 & $\mathrm{U}_{7}$ & Project to provide effective and efficient urban services to the people. \\
\hline 31 & $\mathrm{U}_{8}$ & $\begin{array}{l}\text { Project to set guidelines, standards, and building codes for the sustainable physical } \\
\text { development of the city. }\end{array}$ \\
\hline 32 & $\mathrm{U}_{9}$ & $\begin{array}{l}\text { Project to provide an efficient mechanism for enforcing construction regulations and } \\
\text { preventing construction violations. }\end{array}$ \\
\hline 33 & $\mathrm{U}_{10}$ & $\begin{array}{l}\text { Project to prepare an atlas of accident-prone and unsafe parts of the city to prevent } \\
\text { construction there. }\end{array}$ \\
\hline 34 & $\mathrm{I}_{1}$ & $\begin{array}{l}\text { Project for construction of flood dams, stress-bearing walls of buildings resistant to } \\
\text { earthquakes, sewage collection networks, and anti-storm tree windbreaks }\end{array}$ \\
\hline 35 & $\mathrm{I}_{2}$ & $\begin{array}{l}\text { Projects for constructing transport networks, including lines and stations, to reduce } \\
\text { congestion. }\end{array}$ \\
\hline 36 & $\mathrm{I}_{3}$ & Project for design and construction of digital infrastructure and smart city. \\
\hline 37 & $\mathrm{I}_{4}$ & $\begin{array}{l}\text { Project for water supply, water distribution networks, regulation to prevent water losses, } \\
\text { and reducing water consumption. }\end{array}$ \\
\hline 38 & $\mathrm{I}_{5}$ & $\begin{array}{l}\text { Project for gas distribution network infrastructure and construction of gas stations and } \\
\text { distribution of fossil fuels. }\end{array}$ \\
\hline 39 & $\mathrm{I}_{6}$ & $\begin{array}{l}\text { Project to determine the mechanisms of fair access of people to electricity, gas, gasoline, } \\
\text { and other energies }\end{array}$ \\
\hline 40 & $\mathrm{I}_{7}$ & Project to collect and treat the city's wastewater for reuse \\
\hline 41 & $\mathrm{~N}_{1}$ & $\begin{array}{l}\text { Project for soil protection by reducing construction, increasing the city's green spaces, and } \\
\text { other soil conservation mechanisms. }\end{array}$ \\
\hline 42 & $\mathrm{~N}_{2}$ & $\begin{array}{l}\text { Project to maintain existing water resources through water management methods and } \\
\text { natural resource conservation. }\end{array}$ \\
\hline 43 & $\mathrm{~N}_{3}$ & Project to protect ponds, lakes, and pastures around the city to preserve wildlife and birds. \\
\hline 44 & $\mathrm{~N}_{4}$ & Project to collect surface water and sewage for environmental cleanliness \\
\hline 45 & $\mathrm{~N}_{5}$ & Project to improve water quality and purity and public access to safe drinking water. \\
\hline 46 & $\mathrm{~N}_{6}$ & Project to reduce air pollutants and keep the air clean of toxins and carbon dioxide \\
\hline 47 & $\mathrm{~N}_{7}$ & $\begin{array}{l}\text { Project to reduce noise pollution from workshops and traffic, especially in residential and } \\
\text { educational areas and hospitals. }\end{array}$ \\
\hline 48 & $\mathrm{~N}_{8}$ & Project to clean all components of the environment. \\
\hline 49 & $\mathrm{H}_{1}$ & $\begin{array}{l}\text { Project to increase urban life-quality by standards of the World Health Organization and } \\
\text { striving to achieve them. }\end{array}$ \\
\hline 50 & $\mathrm{H}_{2}$ & $\begin{array}{l}\text { Project to increase the public health rate of the city by health and products and reducing } \\
\text { prices. }\end{array}$ \\
\hline 51 & $\mathrm{H}_{3}$ & $\begin{array}{l}\text { Project to evaluate the rate of public health care services and determine mechanisms to } \\
\text { increase them. }\end{array}$ \\
\hline
\end{tabular}




\begin{tabular}{|l|l|l|}
\hline 52 & $\mathrm{H}_{4}$ & $\begin{array}{l}\text { Project to improve the quantity and quality of hospitals and medical centers. } \\
\text { Additionally, increase beds, equipment, doctors, and nurses. }\end{array}$ \\
\hline 53 & $\mathrm{H}_{5}$ & $\begin{array}{l}\text { Project for monitoring the fair access rate of people to health services and insurance and } \\
\text { ensuring these accesses. }\end{array}$ \\
\hline 54 & $\mathrm{H}_{6}$ & $\begin{array}{l}\text { Project to increase medical equipment and facilities by purchasing vital equipment and } \\
\text { tools. }\end{array}$ \\
\hline 55 & $\mathrm{H}_{7}$ & $\begin{array}{l}\text { Project to determine the mechanism of safe access of people in the community to health } \\
\text { goods and medicines. }\end{array}$ \\
\hline
\end{tabular}

The right-hand column of Table 7 lists the projects related to the city's 55 maximum resilience indicators with optimal investment. This list has been prepared using our workshop experiences and shows only the concept and purpose of the projects. However, it is necessary to plan and implement the mentioned projects according to the characteristics of the city in detail and prepare maps.

Here a question arises. How do the projects listed in Table 7 assist the cities resilience? The projects will support the municipality and other institutions related to urban development to make the city strong against risks. Every project has a task to eliminate a particular known vulnerability of the city. Projects together supply a safe and suitable place for all citizens. The results of the projects will significantly improve the city's capacity to withstand risks, stresses, and shocks. From this perspective, urban resilience has something in common with sustainable development.

\section{Discussions}

Substantial improvement of urbanism's situation considers a city as a whole and demonstrates a close relationship between urban land expansion and demographic urbanization (Song et al., 2021). The experiences show that cities need both planning and development. They also need protection plans against threats. Ignoring this need, even in the past, has led to the destruction of some cities or civilizations. We presented some risks that threaten unstable and unsustainable cities in Table 7.

In the preceding section, we analyzed learnings and appropriations in the process of building cities resiliently. We introduced 55 indicators related to elements of the city that motivated an interconnected network with the ability to work collectively at the urban resilient differentiation.

Our linear program allocates the amount of investment to every indicator group optimally. It led the city to maximum resilience also economic profit. Equations 1-8 understand the relationship between networks, differentiation, and maximum urban hardness in our linear 
programming. Our model understood the principles of interactivity influence of the 55 projects introduced in table 7.

Efficient allocation of investments is the task of urban resilient building scholars.

Here, we interpret and develop our model with a non-linear procedure when considering our 55 projects as independent variables. Given a set of 55 projects in our target function with the capital limitations, we have: $\boldsymbol{i}=\boldsymbol{j}$.

Here, we write:

$$
\begin{aligned}
R_{\mathrm{Pr} \text { offi }} & =\sum_{i=1}^{55} \sum_{j=1}^{55} F_{i j} O \mathrm{P} I_{i j} \\
F_{i i} & =O P I_{i i}
\end{aligned}
$$

We now address the question of how optimal allocation is accessible in maximum resilient building profit and write the Lagrange function for it (Abramowitz \& Stegun, 1964).

$\operatorname{Max} R_{\text {pro }}=\sum_{i j} p_{i j} F^{\beta}{ }_{i j} O P I^{\alpha}{ }_{i j}+\sum_{i} \lambda_{i}\left[c_{i}-\sum_{j} t_{i j}\left(F_{i j}+O P I_{j i}\right)\right]$

Our Kuhn-Tucker conditions (Koopmans and Beckmann, 1957) for the optimal investment as a first derivation test of the model are in (10).

$F_{i j}$ and $O P I_{j i} \geq 0 \Leftrightarrow \frac{p_{i j}}{t_{i j}} \leq\left(\frac{\lambda_{i}}{\alpha}\right)^{\alpha} \times\left(\lambda_{j}\right)^{\beta}$

. In (10), $\lambda_{i}$ and $\lambda_{j}$ are opportunity costs. ${ }^{t_{i j}}$ denotes the time required to implement a given project $i$ to allocate one unit of $j$ 's investment, $p$ is the rate of profits $(O P I)$ in the upgrading of projects.

In the maximization of the $O P I$ by upgrading the $\boldsymbol{p}$ (in practice, we interpret the $\boldsymbol{p}$ to 55 projects) we have $55 !=1.269640335 \times 1073$ solution alternatives. The model finds exact 55 solutions from $1.269640335 \times 1073$. This situation is a linear allocation of the budgets for building the city resiliently.

We introduced a list of required 55 projects to build a city resilient. The projects upgrade the indicators and maximize the economic profits of the building city resiliently. A practical mechanism to realize the suggestions of our model is public participation, particularly the 
cooperation of the influencing factors. Table 6 introduced forces and actors influencing matters related to urban resilience.

We recognized the relationship between urbanization speed and quality, construction scale and management level, economic growth and social development, resource exploitation, and environmental protection. Scholars also noticed that the factors are crucial for urbanization (Guan et al., 2018). In the stages of the urban resilience process described in the previous sections, joint and integrated cooperation between all government departments is essential. Our experience shows that such woven interaction is successful. We shall perform the operations under the responsibility of a competent, knowledge-based, and forward-looking management team. Cooperation between the private and public sectors and responsible international institutions will also advance the resilience of cities.

\section{Conclusions}

This applied research studied the need for urban resilient buildings. The relevance of urban resilience to the reopening of economies took more notice to analyze the dangers that threaten the cities everywhere in the world.

Our method was a multi-phased process of upgrading the indicators of urban resilience. We built a model of resilience with 55 required projects. Every project supported a large variety of solutions, but we learned to select one optimal investment with the help of the model in this paper. The model depended upon various forms of confidence-building tests: on risks. The examinations in the Kuhn-Tucker conditions proved our hypothesis that maximum resilience supplies maximum economic profits.

We argued that these mechanisms replace the authorities integrated into urban management systems and supported rational, scientific, and problem-oriented strategies. This paper presented a procedure of urban building that can allow the six indicator groups to reach a maximum level of efficiency in the post-COVID era. We have suggested that such a building can also upgrade all indicator groups of M, E, U, I, N, and $\mathrm{H}$. The ability of our model to simulate it in different urban systems will support the urban planners, engineers, entrepreneurs, and academicians to build their cities resiliently. 


\section{References}

Abramowitz, M. \& Stegun, I. A. (Eds.). (1964). Handbook of mathematical functions with formulas, graphs, and mathematical tables (Vol. 55). US Government printing office.

Bostrom, N. (2002). Existential risks: Analyzing human extinction scenarios and related hazards. Journal of Evolution and Technology, 9.

Bozza, A., Asprone, D. \& Manfredi, G. (2015). Developing an integrated framework to quantify resilience of urban systems against disasters. Natural Hazards, 78(3), 1729-1748.

Copeland, S., Comes, T., Bach, S., Nagenborg, M., Schulte, Y. \& Doorn, N. (2020).

Measuring social resilience: Trade-offs, challenges and opportunities for indicator models in transforming societies. International Journal of Disaster Risk Reduction, 51, 101799.

Cutter, S. L. (2016). The landscape of disaster resilience indicators in the USA. Natural hazards, 80(2), 741-758.

Dash, S. P., Dipankar, P., Burange, P. S., Rouse, B. T. \& Sarangi, P. P. (2021). Climate change: how it impacts the emergence, transmission, resistance and consequences of viral infections in animals and plants. Critical Reviews in Microbiology, 1-16.

Epstein, P. R., \& Mills, E. (2005). Climate change futures: health, ecological and economic dimensions. The Center for Health and the Global Environment, Harvard Medical School. Fastiggi, M., Meerow, S., \& Miller, T. R. (2021). Governing urban resilience: Organizational structures and coordination strategies in 20 North American city governments. Urban Studies, 58(6), 1262-1285.

Grant, J. (2006). Planning the good community: New urbanism in theory and practice (Vol. 9). Taylor \& Francis.

Guan, X., Wei, H., Lu, S., Dai, Q. \& Su, H. (2018). Assessment on the urbanization strategy in China: Achievements, challenges and reflections. Habitat International, 71, 97-109.

Koopmans, T. C. \& Beckmann, M. (1957). Assignment problems and the location of economic activities. Econometrica: journal of the Econometric Society, 53-76.

Kumar, A., Nagar, S. \& Anand, S. (2021). Climate change and existential threats. In Global Climate Change (pp. 1-31). Elsevier.

Mapar, M., Jafari, M. J., Mansouri, N., Arjmandi, R., Azizinezhad, R. \& Ramos, T. B. (2020). A composite index for sustainability assessment of health, safety and environmental performance in municipalities of megacities. Sustainable Cities and Society, 60, 102164.

Narwal, S. \& Jain, S. (2021). Building Resilient Health Systems: Patient Safety during COVID-19 and Lessons for the Future. Journal of Health Management, 23(1), 166-181. 
OECD (2020). Cities Policy Responses accessible online at https://www.oecd.org/coronavirus/en/

Schofield, H. \& Twigg, J. (2019). Making Cities Sustainable and Resilient.

Shahraki, A. A. (2020). Nature-based management of urban floods to decline risks with case studies.

Shahraki, A. A. (2021). Collect and treat urban wastewater to fight the pandemic disease of COVID-19 effectively.

Siegel, F. R. (2018). Cities and mega-cities: problems and solution strategies. Springer.

Song, X., Wen, M., Shen, Y., Feng, Q., Xiang, J., Zhang, W. \& Wu, Z. (2020). Urban vacant land in growing urbanization: An international review. Journal of Geographical Sciences, 30(4), 669-687.

Song, X., Feng, Q., Xia, F., Li, X. \& Scheffran, J. (2021). Impacts of changing urban landuse structure on sustainable city growth in China: A population-density dynamics perspective. Habitat International, 107, 102296.

Taillant, J. D. (2021). Meltdown: The Earth Without Glaciers. Oxford University Press.

Tan, J., Zhang, P., Lo, K., Li, J. \& Liu, S. (2017). Conceptualizing and measuring economic resilience of resource-based cities: Case study of Northeast China. Chinese Geographical Science, 27(3), 471-481.

Timmerman, P. (1981). Vulnerability resilience and collapse of society. A Review of Models and Possible Climatic Appli-cations. Toronto, Canada. Institute for Environmental Studies, University of Toronto.

Ultramari, C., \& Rezende, D. A. (2007). Urban resilience and cumulative disasters. ISUF 2007- International Seminar on Urban Form

Vale, L. J. \& Campanella, T. J. (2005). The resilient city: How modern cities recover from disaster. Oxford University Press.

Woodruff SC, Meerow S, Stults M, et al. (2018) Adaptation to resilience planning: Alternative pathways to prepare for climate change. Journal of Planning Education and Research pp. 1-12.

World Health Organization. (2017). Roots for Resilience: A health Emergency Risk Profile of the South-East Asia Region.

World Health Organization. (2020). Strengthening preparedness for COVID-19 in cities and urban settings: interim guidance for local authorities (No. WHO/2019-nCoV/Urban preparedness/2020.1). World Health Organization. 
Ye, C., Chen, M., Duan, J. \& Yang, D. (2017). Uneven development, urbanization and production of space in the middle-scale region based on the case of Jiangsu province, China. Habitat International, 66, 106-116. 